\title{
CAVERNOUS HEMANGIOMA OF THE LIVER WITH EXTRAMEDULLARY HEMATOPOIESIS AND MALIGNANT CELLS EMBOLIZATION IN AN ELDERLY PATIENT: A CASE REPORT
}

\author{
Marinko Paunović1, Batrić Vukčević2, Zoran Terzić1, Milorad Magdelinić3, Ljiljana Vučković4, \\ Janja Raonić4, Vanja Balšićs , Jelena Vučinić ${ }^{4}$
}

\begin{abstract}
Cavernous hemangioma is the most common benign tumor of the liver (the incidence ranging from $1.4 \%$ to $52 \%$ ). The etiology of this tumor is unclear, with several hypotheses based on the potential congenital source of the lesions. Extramedullary hematopoiesis is a process of blood cell production outside the bone marrow, usually occurring due to hematologic disease or bone marrow infiltration of other causes. We present a case of 78 year old male with suspected malignant disease of gallbladder, as well as a liver cavernous hemangioma with extramedullary hematopoiesis and malignant cell embolization (endothelial cells positive for CD31 and CD34; and malignant cells positive for pancytokeratin and CDX2).The etiology of extramedullary hematopoiesis in vascular lesions is discussed.
\end{abstract}

Acta Medica Medianae 2020;59(2):114-119.

Key words: cavernous extramedullary, hemangioma, hematopoiesis, malignant

\footnotetext{
${ }^{1}$ Center for Plastic and Reconstructive Surgery, Surgical Clinic, Clinical Center of Montenegro, Podgorica, Montenegro 2University of Montenegro, Faculty of Medicine, Surgical Clinic, Clinical Center of Montenegro, Podgorica, Montenegro

${ }^{3}$ Department of Surgery, General Hospital Berane, Berane, Montenegro

${ }^{4}$ Center for Pathology, Clinical Center of Montenegro,

Podgorica, Montenegro

${ }^{5}$ Special Hospital for Internal Medicine, Vrnjačka Banja, Serbia
}

Contact: Batrić Vukčević

Ljubljanska 1, 81000 Podgorica, Montenegro

E-mail: batricvukcevic@gmail.com

\section{Introduction}

Vascular lesions of the liver may present as cavernous hemangioma $(\mathrm{CH})$, infantile hemangioendothelioma, epitheloid hemangioendothelioma, and angiosarcoma. $\mathrm{CH}$ is the most common benign tumor of the liver, with an incidence ranging from $1.4 \%$ to $52 \%$; usually occurring in old age and in women (1). Autopsy material shows an incidence of $7 \%$. CH structure consists of vascular spaces encased with fibrous tissue and a single layer of endothelial cells. The tumor is usually demarcated from the surrounding tissue. The term "gigantic $\mathrm{CH}^{\text {" is }}$ reserved for tumors larger than 5 centimeters, often containing foci of bleeding, thrombosis, hyalinization, fibrosis and calcification (2).

$\mathrm{CH}$ is usually asymptomatic and diagnosed incidentally. The indications for surgical treatment are the presence of abdominal symptoms, spontaneous/traumatic rupture, rapid growth, KasabachMeritt syndrome as well as an unclear preoperative diagnosis (3). Four types of surgical procedures are performed: liver resection, enucleation, ligation of the hepatic arterial blood vessel and liver transplantation; with the first two being the most common (4). Liver hemangioma etiology is still unclear, with a hypothesis related to the possible congenital source of the lesions (5).

Extramedullary hematopoiesis (EMH) represents the production of blood cells outside the bone marrow. In adults, extramedullary hematopoiesis is a pathological condition usually occurring due to a bone marrow malignant infiltration or fibrosis (6). It is suspected that EMH is triggered by the secretion of the granulocyte colony-stimulating factor (G-CSF) (7).There are several reports of liver hemangiomas harboring EMH foci, without a clear description of the etiological mechanism (8).

This paper contains a description of an interesting case presenting with a liver $\mathrm{CH}$ harboring $\mathrm{EMH}$ and malignant cells emboli.

\section{Case report}

A 78 year old male patient presented with spontaneous subcutaneous hematomas on the lower extremities, fatigue, and weight loss. His previous 
medical history included a nephrectomy 12 years ago (due to a renal cell carcinoma), mechanical aortic valve replacement 5 years ago, hypothyreosis, hypertension, atrial fibrillation and a liver tumor (diagnosed 8 years ago incidentally and regarded as a liver hemangioma based on the ultrasonographic characteristics, measuring $95 \times 40 \mathrm{~mm}$, without changes in size or structure during the past several years).

On examination, the patient was pale and diaphoretic, with a normal clinical examination of the thorax and the abdomen. The complete blood count and the laboratory findings were all in the normal range. Chest X-ray showed no pathological findings. Abdominal ultrasonography showed the previously described liver tumor in the left lobe; irregular density of the gallbladder wall (suggestive of malignant infiltration) with multiple intraluminal stones (maximum size $32 \mathrm{~mm}$ ). Computerized tomography of the abdomen showed the previously described changes, several lesions in the tenth and eleventh thoracic vertebrae, as well as the fourth lumbar vertebra and the base of the sacrum suggestive of metastatic deposits. No other pathological findings were found.

A decision was made to perform a laparoscopic biopsy of the aforementioned liver tumor due to clinical suspicion of malignant disease. Exploration of the abdominal cavity showed the gallbladder infiltrating the liver and the greater omentum. A subcapsular fragment of the liver tissue adjacent to the tumor (size $12 \times 9 \times 8 \mathrm{~mm}$ ) was sent to the histopathological analysis. The tissue showed irregular, wide vascular spaces with uniform endothelial cells and connective tissue, with erythrocytes and hematopoietic cells (Figure 1). Several vascular spaces showed atypical (oval or cubic) cells, with an increased nuclear-cytoplasmic ratio, hyperchromatic nuclei, pathological mitosis, organized in solid or cribriform groups (Figure 2). Immunohistochemistry CD31 and CD34 stain showed a layer of endothelial cells covering the vascular spaces. The atypical cells were positive for pancytokeratin (Figure 3), CDX2, and negative for vimentin, CK7, CK20, HepPar1, CD31, CD34. The conclusion was that the tumor was a liver $\mathrm{CH}$ with elements of $\mathrm{EMH}$ and malignant cells emboli of uncertain origin.

The patient's clinical condition worsened daily. He was hospitalized for blood transfusion two months after the biopsy due to severe sideropenic anemia. During the hospitalization, the patient went into cardiac arrest and passed away after an unsuccessful attempt at cardiopulmonary resuscitation.

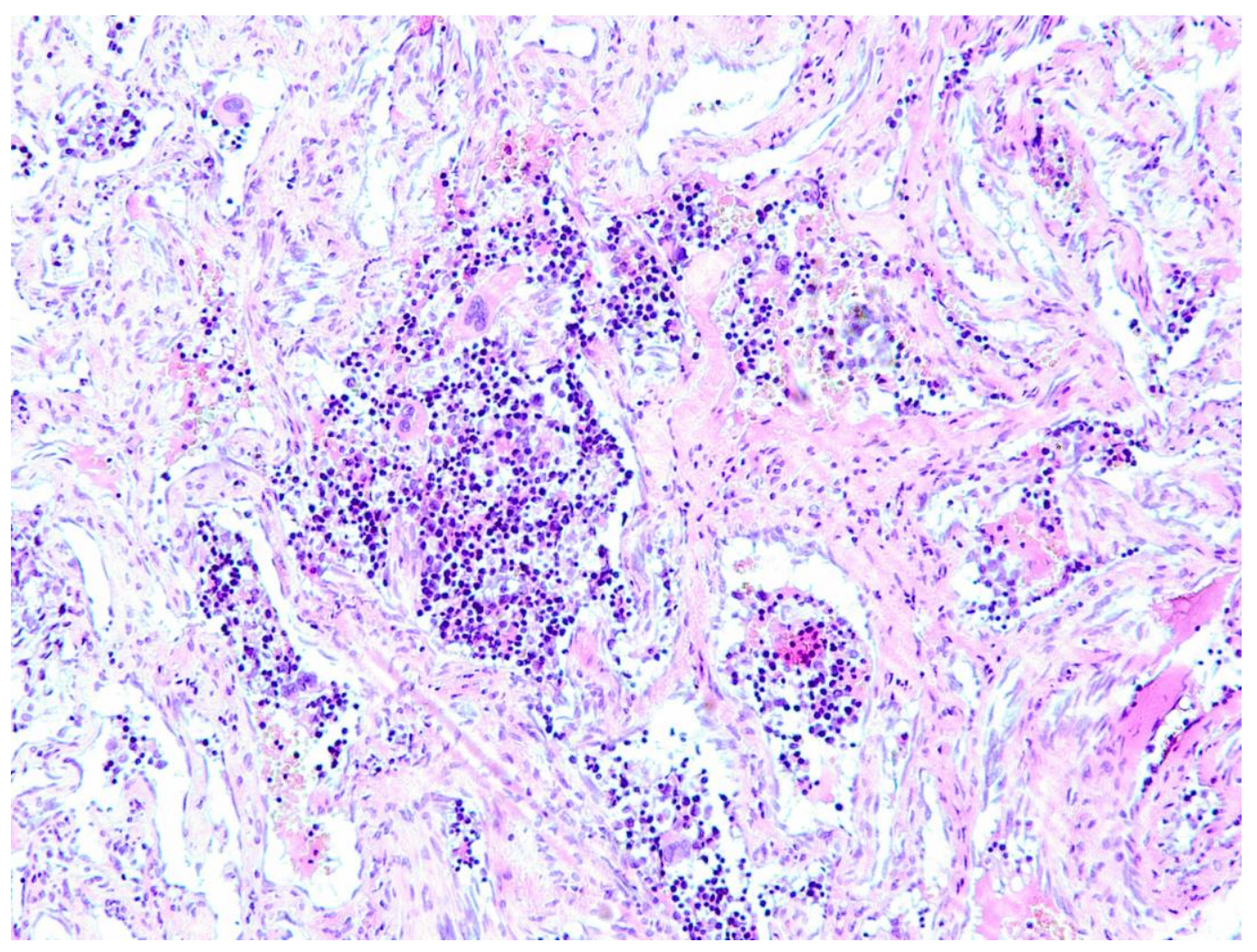

Figure 1. Extramedullary hematopoiesis in a liver hemangioma; hematoxylin-eosin stain, $x 10$ 


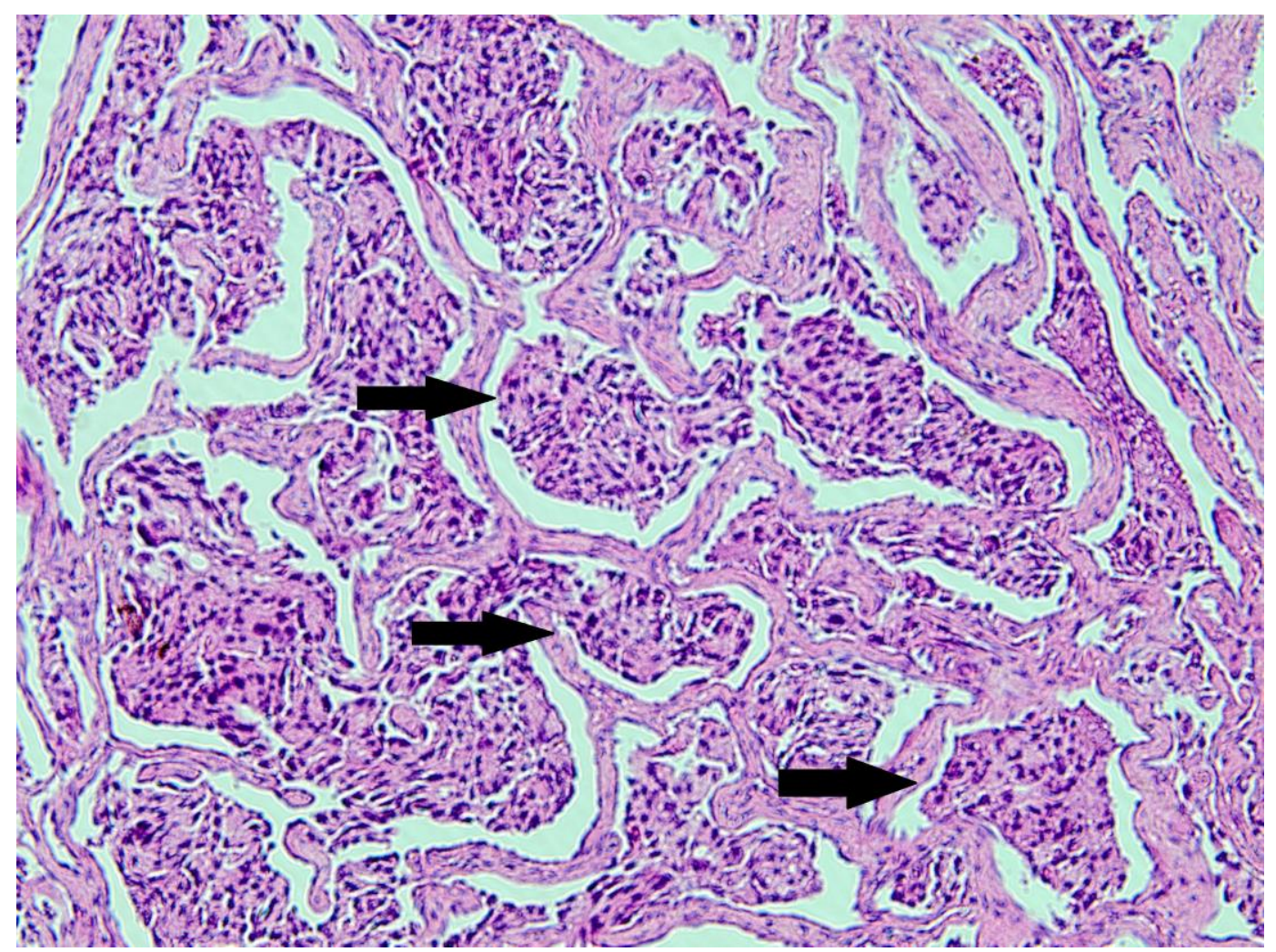

Figure 2. Clusters of tumor cells in a liver hemangioma (indicated by arrows); hematoxylin-eosin stain, x10

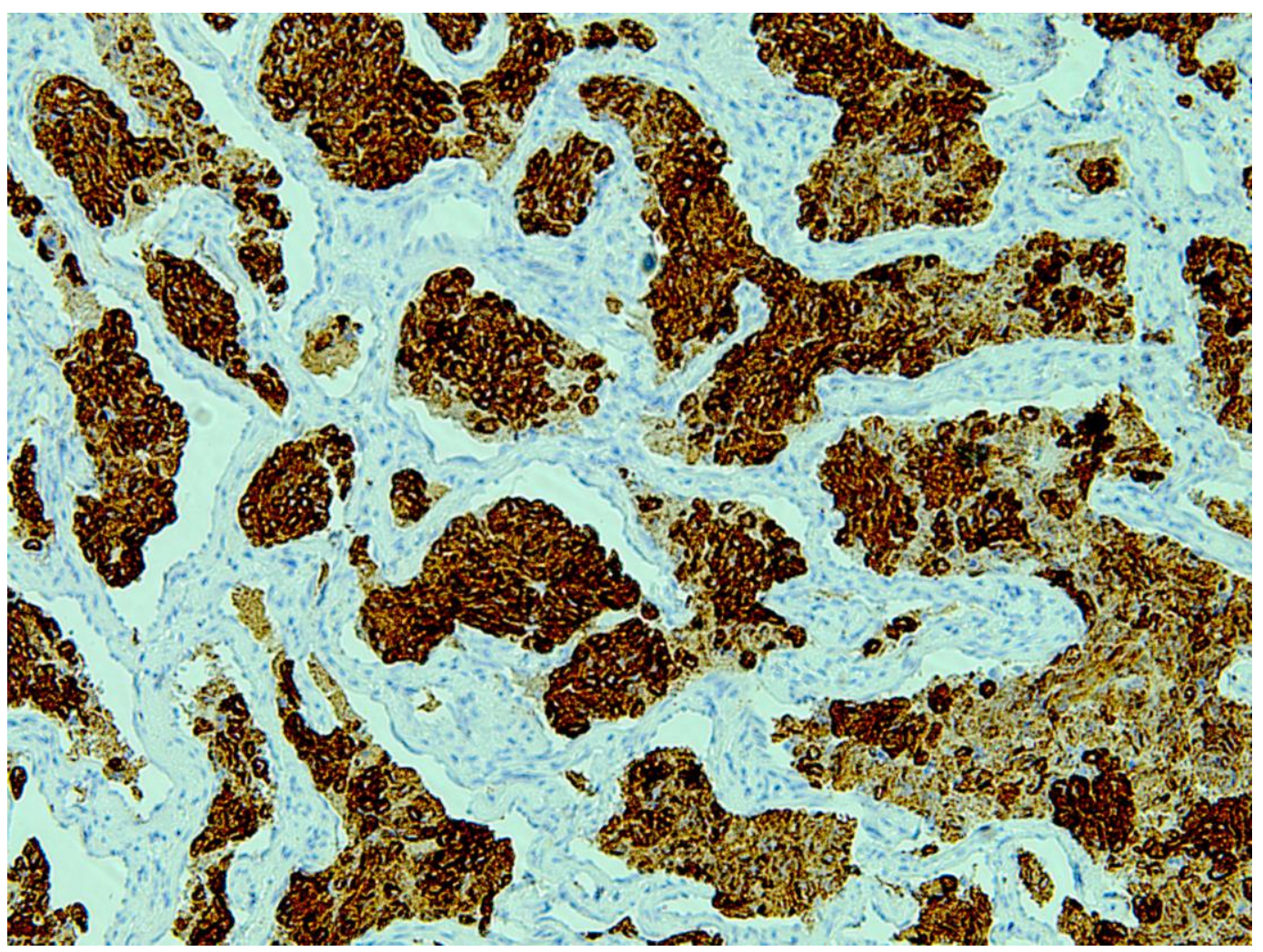

Figure 3. Tumor cells expressing pancytokeratin positivity, $x 10$ 


\section{Discussion}

The case presented herein shows an interesting histopathologic finding in a patient suffering from malignant disease, most likely gallbladder carcinoma. His clinical condition after the laparoscopic biopsy of the liver tumor did not allow for gallbladder surgery to be performed; therefore, a final pathological diagnosis was not reached. The liver hemangioma, which likely existed before the onset of malignant disease, harbored malignant cells as well as hematopoietic cells. It is plausible that the malignant cells in the hemangioma originated from the carcinoma in the gallbladder wall. The histological image of vascular spaces in the liver tumor resembled $\mathrm{CH}$, a lesion which is by itself benign. Liver vascular lesions may present a challenge for the pathologist, regarding the similarity with angiosarcoma. The histological appearance of an anastomosing hemangioma, a sinusoidal pattern of tightly packed capillary channels, may resemble an angiosarcoma-like image (8). However, anastomosing hemangiomas are sharply demarcated - they do not infiltrate the surrounding liver tissue. This differentiates them from hepatic small vessel neoplasm - a tumor showing an infiltrative growth pattern, but without the cytologic atypia characteristic for angiosarcoma (9).

It is interesting to consider whether EMH was triggered by malignant infiltration or it was present in the $\mathrm{CH}$ before the invasion by malignant cells. In order for EMH to occur, multiple systemic (bone marrow failure, excessive hematopoietic stimulation) and local (tissue inflammation and repair, abnormal cytokine secretion) factors are needed (10). In a literature review performed by Bao et al., multiple potential EMH triggers are identified in addition to GCSF: chemotherapeutic agents (e.g. doxorubicin), cytokines or paracrine factors as well as pernicious anemia (11). The original explanation of EMH was based on the probability of the vascular tissue to provide support for the hematopoietic stem cells, similar to their interaction with the endosteum. It is considered that mesenchymal cells (such as nonmyelinating Schwann cells, nesting-expressing cells, and CAR (CXCL12-abundant reticular) cells) support hematopoietic stem cells (12). In addition to the hematologic conditions associated with EMH (thalassemia, sickle cell anemia, hereditary spherocytosis, myeloid neoplasms, and myelodysplastic syndrome), liver EMH may occur in hepatoblastoma, he- patic adenoma and hepatocellular carcinoma (13). The effect of CAR cells (and their expression of CXCL12, otherwise known as the stromal-cell derived factor 1 (SDF1)) in EMH-positive spleen is in the entrapment of the hematopoietic precursor stem cells (12). There are descriptions of EMH occurring in infantile hemangioendothelioma (14). In a series of 157 cases of pyogenic granuloma (lobular capillary hemangioma),Waraasawapati et al. described EMH in $10-8 \%$ of cases (15). Pinczewski and Papadimitriou stress the role of VEGF in EMH associated with epithelioid hemangioendothelioma (16).

Infantile hemangiomas occur in an adequate environment of cytokine secretion, mainly matrix metalloproteinases (MMP) and vascular endothelial growth factor (VEGF), transforming growth factorbeta 1 (TGF-B1) as well as the basic fibroblastic growth factor (b-FGF). They arise from hematopoietic progenitor cells (17). Sequeira-Lopez et al. showed that blood cell progenitors might have a common origin with the blood vessels in the embryo, during the process of chemo-vasculogenesis (18).

\section{Conclusion}

This case report illustrates how a benign liver lesion may contain malignant cells and EMH. The diagnostic workup was not completed due to the patient's condition. The endoscopic evaluation of the upper and lower gastrointestinal tract as well as cholecystectomy should have been performed in order to identify the primary tumor. The pan cytokeratin positivity is indicative of an epithelial tumor, while CDX2 expression exhibited by the malignant cells suggests that the primary tumor is localized in the gastrointestinal tract. The negativity of CD31 suggests that the tumor origin is not vascular.

The CK7-/CK20- pattern is suggestive of hepatocellular carcinoma, germ cell tumor, seminoma, embryonal carcinoma, and other types of tumors, while most bile duct carcinomas are $\mathrm{CK} 7+$ / CK20+. Owing to this, the gastrointestinal origin can be assumed with certain doubt. Future research should aim at ex-plaining the role of VEGF and other cytokines as well as the process of chemovasculogenesis in the occurrence of EMH in hemangiomas (whether EMH arises simultaneously with hemangioma tissue or it sub-sequently settles in the tumor). Furthermore, the potential susceptibility of vascular lesions to har-boring EMH should be examined. 


\section{References}

1. Toro A, Mahfouz AE, Ardiri A, Malaguarnera M, Malaguarnera $G$, Loria $F$, et al. What is changing in indications and treatment of hepatic hemangiomas. A review. Ann Hepatol 2014;13(4):327-39.

[CrossRef] [PubMed]

2. Zeng $Q$, Li $Y$, Chen $Y$, Ouyang $Y$, He X, Zhang $H$. Gigantic cavernous hemangioma of the liver treated by intra-arterial embolization with pingyangmycinlipiodol emulsion: a multi-center study. Cardiovasc Intervent Radiol 2004;27(5):481-5.

[CrossRef] [PubMed]

3. Zhang W, Huang ZY, Ke CS, Wu C, Zhang ZW, Zhang $B X$, et al. Surgical treatment of giant liver hemangioma larger than $10 \mathrm{~cm}$ : a single center's experience with 86 patients. Medicine 2015;94(34):1-7.

[CrossRef] [PubMed]

4. Taseva A, Tasev V, Bonev S, Dimitrova V. Liver hemangiomas--surgical point of view. Khirurgiia (Sofiia) 2014;(2):63-8. [CrossRef] [PubMed]

5. Bajenaru N, Balaban V, Săvulescu F, Campeanu I, Patrascu T. Hepatic hemangioma -review-. J Med Life 2015;8. [CrossRef] [PubMed]

6. Hudson JB, Murad FM, Kunkel JE, Collins BT. Endoscopic ultrasound guided fine-needle aspiration of a splenic hemangioma with extramedullary hematopoiesis. Diagn Cytopathol 2013;41(12):1086-90. [CrossRef] [PubMed]

7. Litam PP, Friedman HD, Loughran TP Jr. Splenic extramedullary hematopoiesis in a patient receiving intermittently administered granulocyte colony-stimulating factor. Ann Intern Med 1993;118(12):954-5. [CrossRef] [PubMed]

8. Lin J, Bigge J, Ulbright TM, Montgomery E. Anastomosing hemangioma of the liver and gastrointestinal tract: an unusual variant histologically mimicking angiosarcoma. Am J Surg Pathol 2013;37(11):1761-5. [CrossRef] [PubMed]

9. Gill RM, Buelow B, Mather C, Joseph NM, Alves V, Brunt EM, et al. Hepatic small vessel neoplasm, a rare infiltrative vascular neoplasm of uncertain malignant potential. Hum Pathol 2016;54:143-51.

[CrossRef] [PubMed]
10. Sohawon D, Lau KK, Lau T, Bowden DK. Extramedullary haematopoiesis: a pictorial review of its typical and atypical locations. J Med Imaging Radiat Oncol 2012;56(5):534-8. [CrossRef] [PubMed]

11. Bao Y, Liu Z, Guo M, Li B, Sun X, Wang L. Extramedullary hematopoiesis secondary to malignant solid tumors: a case report and literature review. Cancer Management and Research 2018;10:1461-70. [CrossRef] [PubMed]

12. Yamamoto K, Miwa $Y$, Abe-Suzuki S, Abe S, Kirimura S, Onishi I, et al. Extramedullary hematopoiesis: Elucidating the function of the hematopoietic stem cell niche (Review). Mol Med Rep 2016;13(1):587-91. [CrossRef] [PubMed]

13. Tsamandas $A C$, Jain $A B$, Raikow RB, Demetris $A J$, Nalesnik MA, Randhawa PS. Extramedullary hematopoiesis in the allograft liver. Mod Pathol 1995;8: 671-4. [PubMed]

14. Jhuang JY, Ling LW, Hsieh MS. Adult capillary hemangioma of the liver: case report and literature review. Kaohsiung Journal of Medical Sciences 2011; 27:344-7. [CrossRef] [PubMed]

15. Waraasawapati S, Koonmee S, Kusama H, Kudo M. Extramedullary hematopoiesis in pyogenic granuloma. Pathol Int 2013;63(10):492-5. [CrossRef] [PubMed]

16. Pinczewski J, Papadimitriou JC. Aberrant VEGF expression associated with neoplasm-induced extramedullary hematopoiesis in an epithelioid hemangioendothelioma: a case report. Int J Surg Pathol 2011; 19(5):662-6. [CrossRef] [PubMed]

17. Kumar A. Haemangioma: a review of the literature and an unusual case report. EMJ 2017;2(1):31-5. [CrossRef]

18. Sequeira Lopez ML, Chernavvsky DR, Nomasa T, Wall $L$, Yanagisawa $M$, Gomez RA. The embryo makes red blood cell progenitors in every tissue simultaneously with blood vessel morphogenesis. Am J Physiol Regul Integr Comp Physiol 2003;284(4):R1126-37. [CrossRef] [PubMed] 


\title{
KAVERNOZNI HEMANGIOM JETRE SA EKSTRAMEDULARNOM HEMATOPOEZOM I EMBOLIZACIJOM MALIGNIM ĆELIJAMA: PRIKAZ SLUČAJA
}

\author{
Marinko Paunović1, Batrić Vukčević2, Zoran Terzić1, Milorad Magdelinić3 ${ }^{3}$, Ljiljana Vučković4, \\ Janja Raonićt, Vanja Balšićs, Jelena Vučinićt
}

\begin{abstract}
${ }^{1}$ Centar za plastičnu i rekonstruktivnu hirurgiju, Hirurška klinika, Klinički centar Crne Gore, Podgorica, Crna Gora ${ }^{2}$ Univerzitet Crne Gore, Medicinski fakultet, Hirurška klinika, Klinički centar Crne Gore, Podgorica, Crna Gora ${ }^{3}$ Odeljenje hirurgije, Opšta bolnica Berane, Berane, Crna Gora

${ }^{4}$ Centar za patologiju, Klinički centar Crne Gore, Podgorica, Crna Gora

${ }^{5}$ Specijalna bolnica za interne bolesti, Vrnjačka Banja, Srbija

Kontakt: Batrić Vukčević

Ljubljanska 1, 81000 Podgorica, Crna Gora

E-mail: batricvukcevic@gmail.com

Kavernozni hemangiom jetre je najčešći benigni tumor jetre (sa incidencijom u rasponu od $1,4 \%$ do $52 \%$ ). Etiologija tumora je nejasna, sa nekoliko hipoteza koje se baziraju na mogućem kongenitalnom uzroku lezije. Ekstramedularna hematopoeza je proces produkcije krvnih ćelija van koštne srži, najčešće usled hematoloških bolesti ili fibroze koštne srži. Prezentujemo slučaj muškarca starog 78 godina sa sumnjom na malignitet žučne kese, kao i sa kavernoznim hemangiomom jetre sa ekstramedularnom hematopoezom i embolizacijom malignim ćelijama (endotelne ćelije pozitivne na CD31 i CD34; maligne ćelije pozitivne na pan-citokeratin i CDX2). Diskutovana je etiologija ekstramedularne hematopoeze u vaskularnim lezijama.
\end{abstract}

Acta Medica Medianae 2020;59(2):114-119.

Ključne reči: kavernozni hemangiom, ekstramedularna hematopoeza, malignitet 